\title{
BMJ Global Health Comparison of different approaches to antibiotic restriction in food-producing animals: stratified results from a systematic review and meta-analysis
}

\author{
Karen L Tang, ${ }^{1}$ Niamh P Caffrey, ${ }^{2}$ Diego B Nóbrega, ${ }^{3}$ Susan C Cork, ${ }^{2}$ \\ Paul E Ronksley, ${ }_{4}^{4}$ Herman W Barkema, ${ }^{3}$ Alicia J Polachek, ${ }^{5}$ Heather Ganshorn, ${ }^{6}$ \\ Nishan Sharma, ${ }^{5}$ James D Kellner, ${ }^{7}$ Sylvia L Checkley, ${ }^{2}$ William A Ghali ${ }^{1}$
}

To cite: Tang KL, Caffrey NP, Nóbrega DB, et al. Comparison of different approaches to antibiotic restriction in food-producing animals: stratified results from a systematic review and metaanalysis. BMJ Global Health 2019;4:e001710. doi:10.1136/ bmjgh-2019-001710

Handling editor Peter MacGarr Rabinowitz

- Additional material is published online only. To view please visit the journal online (http://dx.doi.org/10.1136/ bmjgh-2019-001710).

Received 14 May 2019 Revised 26 July 2019 Accepted 18 August 2019

Check for updates

(c) Author(s) (or their employer(s)) 2019. Re-use permitted under CC BY-NC. No commercial re-use. See rights and permissions. Published by BMJ.

For numbered affiliations see end of article.

Correspondence to

Dr Karen L Tang;

klktang@ucalgary.ca

\section{ABSTRACT}

Background We have previously reported, in a systematic review of 181 studies, that restriction of antibiotic use in food-producing animals is associated with a reduction in antibiotic-resistant bacterial isolates. While informative, that report did not concretely specify whether different types of restriction are associated with differential effectiveness in reducing resistance. We undertook a subanalysis of the systematic review to address this question.

Methods We created a classification scheme of different approaches to antibiotic restriction: (1) complete restriction; (2) single antibiotic-class restriction; (3) single antibiotic restriction; (4) all non-therapeutic use restriction; (5) growth promoter and prophylaxis restriction; (6) growth promoter restriction and (7) other/ undetermined. All studies in the original systematic review that were amenable to meta-analysis were included into this substudy and coded by intervention type. Metaanalyses were conducted using random effects models, stratified by intervention type.

Results A total of 127 studies were included. The most frequently studied intervention type was complete restriction $(n=51)$, followed by restriction of non-therapeutic $(n=33)$ and growth promoter $(n=19)$ indications. None examined growth promoter and prophylaxis restrictions together. Three and seven studies examined single antibiotic-class and single antibiotic restrictions, respectively; these two intervention types were not significantly associated with reductions in antibiotic resistance. Though complete restrictions were associated with a $15 \%$ reduction in antibiotic resistance, less prohibitive approaches also demonstrated reduction in antibiotic resistance of $9 \%-30 \%$.

Conclusion Broad interventions that restrict global antibiotic use appear to be more effective in reducing antibiotic resistance compared with restrictions that narrowly target one specific antibiotic or antibiotic class. Importantly, interventions that allow for therapeutic antibiotic use appear similarly effective compared with those that restrict all uses of antibiotics, suggesting that complete bans are not necessary. These findings directly inform the creation of specific policies to restrict antibiotic use in food-producing animals.

\section{Key questions}

What is already known?

- Antimicrobial resistance (AMR) is a threat to public health, with the Tripartite Collaboration (WHO, the Food and Agriculture Organisation of the United Nations and the World Organisation for Animal Health) calling for a One Health approach to address this crisis.

- A recent systematic review and meta-analysis suggested that, in general, interventions that restrict antibiotic use in food-producing animals are effective in reducing AMR in these animals and in certain subgroups of human population, though whether certain types of interventions are more effective than others remains unknown.

\section{What are the new findings?}

- A wide spectrum of interventions, from limiting antibiotics for growth promoter or feed additive purposes only to limiting all uses of antibiotics (including for therapy), were associated with a $9 \%-30 \%$ absolute reduction in antibiotic resistance.

- Interventions that restrict the use of only one antibiotic or antibiotic class were not significantly associated with a reduction in antibiotic resistance.

What do the new findings imply?

- Highly targeted interventions that limit the use of only a single antibiotic or antibiotic class may have limited effectiveness in reducing antibiotic resistance.

- Interventions that broadly target overall antibiotic use or that restrict the use of multiple antibiotic classes are recommended as these appear to be associated with reductions in antibiotic resistance, though a complete restriction of antibiotics does not appear to be necessary.

\section{INTRODUCTION}

Antimicrobial resistance (AMR) has been recognised as a threat to public health worldwide, being associated with increased morbidity, mortality and societal costs. ${ }^{1-4}$ It is 
estimated that by 2050 , AMR will contribute to 10 million deaths per year, a $2 \%-3.5 \%$ reduction in gross domestic product, and cost $\$ 100$ trillion US $\$$ worldwide. ${ }^{5}$ Over-prescription and unnecessary non-prescription antibiotic use are the main contributors to increase AMR in humans. ${ }^{6}$ Widespread antibiotic use in agriculture and aquaculture also likely plays a role, ${ }^{7-9}$ especially as many of the antibiotics used in animals are the same, or are in the same class, as antibiotics used in humans. ${ }^{810-12}$ The WHO, the Food and Agriculture Organisation of the United Nations and the World Organisation for Animal Health, known as the Tripartite Collaboration, have called for a One Health approach, with recognition that animal, human and environmental health are linked, to address the problem of AMR. ${ }^{13}$

A systematic review conducted by our group showed that interventions that aimed to reduce antibiotic use in food-producing animals are associated with a reduction in AMR in these animals, as well as in certain subgroups of the human population (particularly those with direct contact with animals). ${ }^{14}$ These findings were critical in demonstrating that reducing antibiotic use in agriculture is an effective avenue by which to combat the growing problem of AMR worldwide. However, the studies included in the systematic review used many different approaches to reduce and/or to restrict antibiotic use. Our report did not address whether different types and extent of antibiotic restriction lead to different levels of reduction in antibiotic resistance. That is, though antibiotic restrictions appear, in a broad sense, to be effective in reducing resistance, it is unclear whether specific types of restrictions are more effective than others.

Antibiotics can be used in food-producing animals for therapeutic purposes (ie, to treat existing infectious disease), for disease control within a herd or flock, and for non-therapeutic purposes. ${ }^{15}$ This results in a wide spectrum of possible approaches to antibiotic restriction. The least restrictive approaches would include those that prohibit the use of only one antibiotic or antibiotic class, and those that restrict the use of antibiotics for specific non-therapeutic indications only such as for growth promotion. On the opposite end of the spectrum is the complete prohibition of the use of all antibiotics, for any indication. With the least restrictive approaches, there is risk of increased use of other antibiotics in the place of the restricted $\operatorname{drug}(\mathrm{s})$, thereby raising the question of whether such measures actually reduce AMR. ${ }^{16} 17$ On the other hand, while antibiotic-free strategies may be effective in reducing AMR, the inability to use antibiotics, even to treat diagnosed clinical infectious diseases, is detrimental for animal production and economics as well as to animal welfare. ${ }^{18} 19$

The development of national and international guidelines and policies requires greater detail about the effectiveness of different interventions so that specific recommendations can be made as to what type of antibiotic restrictions should be implemented. We were commissioned by the WHO to undertake a subanalysis of the original systematic review and meta-analysis to explore the associations between different interventions that restrict antibiotic use in food-producing animals and antibiotic resistance in these animals, to inform the WHO Guidelines on the use of antibiotics in food-producing animals. ${ }^{20}$ Our findings provide crucial insights into the type and extent of antibiotic restriction that optimises desired effects of reducing AMR.

\section{METHODS}

The methods for the broader systematic review and meta-analysis, of which this is a substudy, have been described in detail in a prior publication. ${ }^{14}$ The systematic review and meta-analysis was conducted following a predetermined protocol and in accordance with Preferred Reporting Items for Systematic Reviews and Meta-Analyses reporting standards. ${ }^{21}$ Ethics approval was not required, as the study is based on a review of published literature.

\section{Search strategy}

The search strategy consisted of controlled vocabulary and keywords, under three themes: animal populations of interest (theme 1), resistance to antibiotics (theme $2)^{22} 23$ and interventions to restrict antibiotic use (theme 3 ). These three themes were combined with the Boolean operator 'AND'. Electronic databases were searched in initially searched in July 2016, and again in January 2017. Databases included Agricola (1970-present), AGRIS (http://agris.fao.org), BIOSIS Previews (1980present), CAB Abstracts (1910-present), MEDLINE (1946-present), EMBASE (1974-present), Global Index Medicus (http://www.globalhealthlibrary.net; non-MEDLINE indices included AIM (AFRO), LILACS (AMRO/ PAHO), IMEMR (EMRO), IMSEAR (SEARO), WPRIM (WPRO), WHOLIS (KMS) and SciELO), ProQuest Dissertations and Science Citation Index (1899present). No limits were placed based on publication date or language. An update to the search was conducted on 8 July 2019, focusing on the electronic databases MEDLINE, EMBASE, CAB Abstracts, and AGRIS.

Reference lists of included articles (published 2010 onward) were manually searched. Grey literature searching included websites of relevant health agencies, professional associations and other specialised databases. The WHO Guideline Development Group as well as experts in antimicrobial use and resistance, veterinary medicine and animal health policy were contacted to identify potential missed, ongoing or unpublished studies.

\section{Abstract screening and full-text review}

Two authors independently reviewed all identified titles and abstracts for eligibility. Only articles reporting original research that described an intervention aimed to reduce antibiotic use in animals and described antibiotic resistance in animals or humans were selected for full-text review. At the full-text review stage, articles were 
retained and ultimately included into this substudy if they were original research meeting the following inclusion criteria: (1) population studied included food-producing animals (within the classifications of avian, swine, bovine, caprine, camel, equine, rabbit, ovine, fish, bees, molluscs and crustaceans); (2) interventions restricted the use of antibiotics in food-producing animals; (3) presence of a comparator group without antibiotic use restrictions (historical comparators were considered eligible); (4) outcomes reported phenotypic antibiotic resistance in bacteria in food-producing animals and (5) sufficient data reported to calculate risk differences (RDs) in proportion of isolates with antibiotic resistance in the intervention versus the comparator group (to allow for meta-analysis).

\section{Data extraction and assessment of individual study quality}

Two authors (KT and NC) extracted data from each included study using a predesigned form. Data extracted included study design, country, animal characteristics, sampling characteristics, description of intervention, description of comparator, bacteria investigated, and prevalence of antibiotic resistance in intervention and comparator groups. The same authors independently assessed the methodological quality of each study based on pre-specified study quality indicators adapted from the Downs and Black checklist. ${ }^{24}$ The results of the quality assessment are described in a prior publication. $^{14}$

\section{Patient and public involvement}

Due to the nature of the research question, which was defined by the WHO and which used data from our prior review of published literature, patients were not involved in this study.

\section{Creation of an intervention classification scheme}

The WHO commissioned this study to inform the development of Guidelines on this topic. The initial request for a classification scheme therefore originated from the WHO Advisory Group on Integrated Surveillance of Antimicrobial Resistance (WHO AGISAR) Guideline Development Group committee members. Because there is no widely accepted classification scheme to categorise interventions that restrict and/or reduce antibiotic use, we developed one from the ground-up, based on the types of interventions found in the literature. The preliminary categories that were developed were then presented to WHO AGISAR for input and feedback, and then iteratively refined.

We began by establishing standard terminology to be used in this classification scheme, as different jurisdictions may use terminology differently. For example, the definition for metaphylaxis provided by the US Department of Agriculture includes the prophylactic use of antibiotics in healthy animals to prevent disease (even when there are no clinically affected animals present), ${ }^{25}$ whereas the definition from the European Medicines Agency does not. ${ }^{26}$ Furthermore, some consider metaphylaxis to be a therapeutic indication of antibiotic use (ie, it is considered to be 'group treatment' of animals) ${ }^{26}$ while others note that antibiotic use is only therapeutic if administered in clinically infected animals. ${ }^{27}$ The latter definition would therefore consider metaphylaxis not to be therapy, but rather disease prevention. We consulted the veterinary experts on the study team along with the WHO Guideline Development Group for definitions for the terms 'antibiotic growth promotor', 'metaphylaxis', 'prophylaxis', 'non-therapeutic antibiotic use' and 'therapeutic antibiotic use'. Consensus was reached for the definitions provided in table 1 , which were then used in our classification scheme.

In total, we created seven categories of interventions (table 2): (1) complete restriction; (2) restriction of use of a single antibiotic class; (3) restriction of use of a single antibiotic; (4) all non-therapeutic use restriction; (5) growth promoter and prophylaxis restriction; (6) growth promoter restriction and (7) other/undetermined. Each intervention was assigned only one category. If a study included more than one intervention, then each intervention was classified separately based on

Table 1 Definitions for terms used in the classification scheme for interventions

\begin{tabular}{|c|c|}
\hline Terminology & Definition \\
\hline Antibiotic growth promoter & $\begin{array}{l}\text { Administration of subtherapeutic doses of antibiotics to stimulate growth in animals or to } \\
\text { increase feed efficiency. }{ }^{27} 167\end{array}$ \\
\hline Non-therapeutic antibiotic use & $\begin{array}{l}\text { Administration of antibiotics to animals without identifiable infectious disease. }{ }^{167} \text { This } \\
\text { includes antibiotic use for growth promotion, disease prophylaxis and metaphylaxis. }\end{array}$ \\
\hline Metaphylaxis & $\begin{array}{l}\text { Treatment of a group of animals without evidence of disease, but which are likely in an } \\
\text { incubation phase, due to being in close contact with clinically diseased animals. }{ }^{26}\end{array}$ \\
\hline Prophylaxis & $\begin{array}{l}\text { Administration of antibiotics to animals at high risk of infectious disease (but without } \\
\text { current disease and where there is no known disease in the herd or flock). }{ }^{167} \text { Prophylaxis } \\
\text { is commonly used when environmental conditions or changes portend increased risk for } \\
\text { infection. Examples of such conditions include transport of animals and confining animals to } \\
\text { small, crowded spaces. }{ }^{167}\end{array}$ \\
\hline Therapeutic antibiotic use & $\begin{array}{l}\text { Administration of antibiotics to treat animals with clinical evidence of infectious disease } \\
\text { only. }{ }^{27167}\end{array}$ \\
\hline
\end{tabular}


Table 2 Classification of interventions that restrict antibiotic use in food-producing animals

\begin{tabular}{ll}
\hline Category & Description \\
\hline $\begin{array}{l}\text { Complete restriction } \\
\text { Single antibiotic-class restriction }\end{array}$ & $\begin{array}{l}\text { Restriction on the use of all antibiotics } \\
\text { Restriction on the use of one class of antibiotics, for all indications of use }\end{array}$ \\
\hline All non-therapeutic use restriction & $\begin{array}{l}\text { Restriction on the use of a single individual antibiotic, for all indications of use } \\
\text { promotion, prophylaxis and metaphylaxis (treatment of diseased animals permitted } \\
\text { only) }\end{array}$ \\
$\begin{array}{ll}\text { Growth promoter and prophylaxis } \\
\text { restriction }\end{array}$ & $\begin{array}{l}\text { Restriction on the use of antibiotics for the non-therapeutic indications of growth } \\
\text { promotion and prophylaxis (treatment and metaphylaxis permitted) }\end{array}$ \\
Growth promoter restriction & $\begin{array}{l}\text { Restriction on the use of antibiotics for purposes of growth promotion only (treatment, } \\
\text { metaphylaxis and prophylaxis permitted) }\end{array}$ \\
Other/undetermined & $\begin{array}{l}\text { Inability to classify the intervention type into one of the above categories, or where the } \\
\text { indication for antibiotic use that is targeted by the intervention is not specified }\end{array}$ \\
\hline
\end{tabular}

the above approach. The 'growth promoter restriction' category did not require the restriction of all available antibiotic growth promoters. That is, interventions that restricted one or more growth promoters were eligible to be included in this category, even if there was residual use of other non-restricted growth promoters (eg, ionophores and flavophospholipols). The 'other/undetermined' category captures studies that did not specify the type of antibiotic use or indication that was targeted in the antibiotic restriction strategy. This includes studies, for example, that compare regions or farms using 'more' versus 'less' antibiotics with no indication of what is specifically targeted or described, or studies that assess the impact of reducing antibiotic use in a jurisdiction without delineating how this is achieved. An algorithm was created to ensure reproducibility in how interventions are classified into the different categories (figure 1).

We anticipated that some studies may use labels to define the intervention, without further description. Such labels might include 'organic' or 'antibiotic-free' production. We established a set of decision rules a priori. These included the following:

a. Interventions involving organic production in the USA were classified as 'complete restriction', as organic certification in the USA specifies that animals are raised without any exposure to antibiotics. ${ }^{28}$

b. Interventions involving organic production in Europe were classified as 'all non-therapeutic use restriction' as the European Commission on organic production specifies that animals are allowed limited antibiotics for therapeutic purposes. ${ }^{29} 30$

c. We referred to organic certification standards, if cited, for interventions involving organic production in countries outside of the USA and Europe.

d. Interventions where no such certifications exist (eg, 'antibiotic-free', 'pasture' or 'free range') were classified as 'undetermined/other' unless sufficient detail was provided for classification into any other category.

\section{Outcome measure}

Antibiotic resistance was considered a dichotomous outcome, as classified by the individual primary studies. Intermediate susceptibility was considered susceptible. Absolute RDs were calculated for each individual antibiotic in each study by subtracting the proportion of resistant isolates in the control group from the proportion in the intervention group.

\section{Meta-analysis}

All meta-analyses were stratified by intervention type. To allow for meaningful and adequately powered analysis within each intervention stratum, all included studies were pooled, regardless of the animal populations, sample types or bacterial species studied. A single effect estimate (absolute RD) was generated for each study by conducting within-study meta-analysis using random effects models.

Absolute RDs across all studies were then pooled using DerSimonian and Laird random-effects models. This method was chosen due to the known clinical heterogeneity across studies, with studies from different regions examining different animal populations, sample types and bacteria. ${ }^{31}$ A lower prevalence of antibiotic resistance in the intervention group compared with the control group would result in a negative pooled absolute RD. Recognising that RDs must be interpreted in the context of baseline prevalence of antibiotic resistance, we conducted additional meta-analysis, pooling the prevalence of antibiotic resistance in the comparator groups, stratified by intervention type, using random-effects models. Heterogeneity across studies was evaluated using the $\mathrm{I}^{2}$ statistic. $^{3233}$ Meta-regression was conducted, with each intervention type being a covariate. A joint test for all covariates was conducted, to test whether intervention type was associated with the size of the outcome effect (ie, antibiotic resistance).$^{34}$ 




Figure 1 Algorithm for the classification of interventions to restrict antibiotic use in food-producing animals.

\section{Role of the funding source}

The WHO was involved in both the original systematic review and meta-analysis, as well as this substudy. They were involved in developing the research question, the study design and the study protocol. They had no involvement in data extraction or interpretation of findings. The authors have been given permission by the WHO to publish this article.

\section{RESULTS \\ Identification of studies}

The initial search strategy identified 9008 citations from electronic databases. An additional 56 studies were identified by contacting experts, and another 82 by searching reference lists. After removal of duplicates, 5945 records underwent title and abstract review. Of these, 5559 records were not relevant to the research objective, and 386 full-text articles were reviewed. A total of 181 studies were included in the larger original systematic review. Of these, two were excluded as they examined AMR outcomes in humans but not animals, 17 were excluded as they reported presence of resistant genetic elements with no phenotypic resistance outcomes, and 48 were excluded as there were insufficient data to allow for meta-analysis. Therefore, 114 studies from the original systematic review were included in this substudy. In addition, an update to the search was conducted July 2019, at which time a total of 1208 new records were identified. After duplicates were removed, 703 underwent title and abstract review. Of these, 659 were excluded as were not relevant to the research objective, and 44 full-text articles were reviewed, of which 13 ultimately met criteria to be included into this study. In total, 127 studies were included into this systematic review and meta-analysis (figure 2).

\section{Study characteristics}

Of the 127 studies, 51 restricted all use of antibiotics (complete restriction), ${ }^{35-85}$ three restricted use of a single antibiotic class ${ }^{86-88}$ and seven restricted use of a single specific antibiotic. ${ }^{89-95}$ In all, 33 studies restricted use of antibiotics for all non-therapeutic purposes, ${ }^{48-127}$ and 19 restricted antibiotic growth promoters only. ${ }^{128-146}$ A total of 21 studies were classified into the "other/ undetermined' category. ${ }^{52} 5383100137$ 147-162 Of note, seven studies consisted of two different interventions and were therefore included into two separate categories. 48525383100122137 


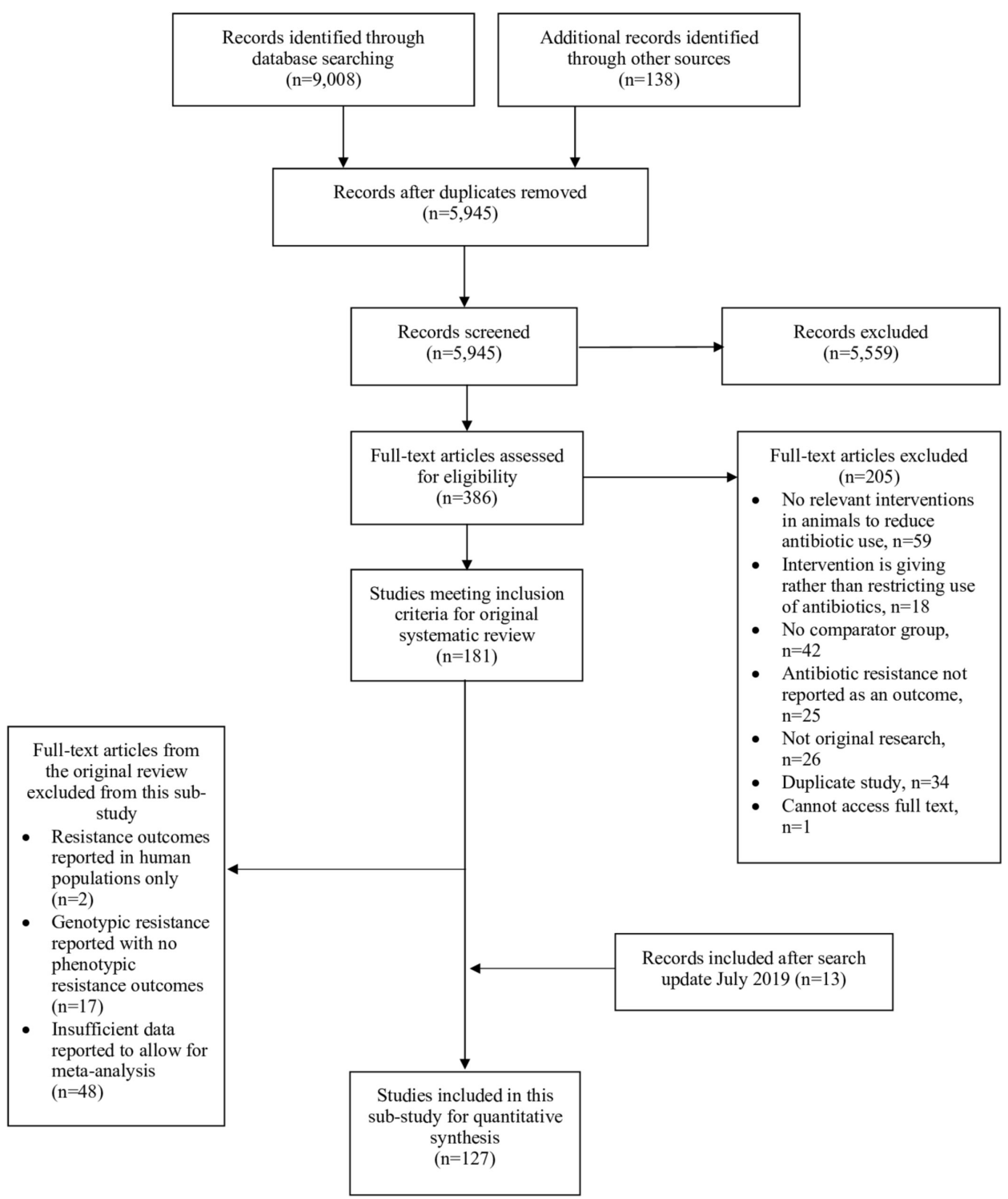

Figure 2 PreferredReporting Items for Systematic Reviews and Meta-Analyses flow diagram of the study selection process.

A summary of study characteristics is found in table 3 . In total, 114 of the 127 studies were journal articles. There were eight dissertations and six meeting abstracts/ conference proceedings. The majority had a cross-sectional design. Poultry $(\mathrm{n}=69)$ was the most commonly studied animal population, followed by swine $(n=42)$ and dairy cattle $(\mathrm{n}=19)$. Antibiotic resistance was most commonly assessed in the bacterial group Enterobacteriaceae. In all, 65 studies were from North America and 53 were from Europe. Few study populations were from Asia $(n=6)$, Africa $(n=1)$, Australasia $(n=2)$ and South America $(n=1)$. Detailed study characteristics for individual studies can be found in a prior publication, ${ }^{14}$ as well as in online supplementary appendix 1 table S1.

\section{Meta-analysis by intervention category}

All intervention types were associated with a significantly lower pooled risk of antibiotic resistance in the intervention group compared with the comparator group except for single antibiotic-class and single antibiotic restrictions ( $\mathrm{RD}-0.02,95 \%$ CI $-0.10,0.05$ and $\mathrm{RD}-0.11,95 \%$ CI $-0.21,0.01$ respectively, see table 4$)$. The pooled risk reduction of antibiotic resistance was greatest for growth promoter restrictions (RD $-0.30,95 \%$ CI -0.42 to -0.17$)$. That is, for interventions that restricted the use of antibiotic growth promoters, there was a $30 \%$ reduction in the proportion of isolates that were antibiotic resistant in the intervention group compared with the comparator group. Similarly, there was a $10 \%$ and $15 \%$ reduction in the proportion of antibiotic-resistant isolates for interventions that restricted all non-therapeutic uses of antibiotics and interventions that completely restricted all (non-therapeutic and therapeutic) uses of antibiotics, respectively. The $\mathrm{I}^{2}$ for each intervention stratum ranged between $89.0 \%$ and $98.5 \%$, suggesting the presence of considerable heterogeneity. The meta-regression joint $p$ value was 0.046 , suggesting that the type of intervention significantly affected the magnitude of reduction in antibiotic resistance. 
Table 3 Summary of study characteristics

\begin{tabular}{|c|c|c|c|c|c|c|c|}
\hline Study characteristic (n) & $\begin{array}{l}\text { Complete } \\
\text { restriction } \\
(n=51) \\
n(\%)\end{array}$ & $\begin{array}{l}\text { Antibiotic- } \\
\text { class } \\
\text { restriction } \\
(n=3) \\
n(\%)\end{array}$ & $\begin{array}{l}\text { Individual } \\
\text { antibiotic } \\
\text { restriction } \\
(n=7) n(\%)\end{array}$ & $\begin{array}{l}\text { All non- } \\
\text { therapeutic } \\
\text { use restriction } \\
(n=33) \\
n(\%)\end{array}$ & $\begin{array}{l}\text { Growth } \\
\text { promoter } \\
\text { restriction } \\
(n=19) \\
n(\%)\end{array}$ & $\begin{array}{l}\text { Other/ } \\
\text { undetermined } \\
(n=21) n(\%)\end{array}$ & $\begin{array}{l}\text { Total number } \\
\text { of studies } \\
n=127\end{array}$ \\
\hline \multicolumn{8}{|l|}{ Type of article } \\
\hline Journal article & $43(84.3)$ & $3(100.0)$ & $7(87.5)$ & 31 (93.9) & $19(100.0)$ & $16(76.2)$ & 114 \\
\hline Abstract only & $4(7.8)$ & - & - & $1(3.0)$ & - & $3(14.3)$ & 6 \\
\hline Dissertation & $4(7.8)$ & - & $1(12.5)$ & $1(3.0)$ & - & $2(9.5)$ & 8 \\
\hline \multicolumn{8}{|l|}{ Study design } \\
\hline Non-randomised controlled trial & - & - & $1(14.3)$ & - & - & - & 1 \\
\hline Cross-sectional & $45(88.2)$ & $1(33.3)$ & $2(28.6)$ & $28(84.8)$ & $8(42.1)$ & $16(76.2)$ & 95 \\
\hline Longitudinal & $6(11.8)$ & $2(66.7)$ & $4(57.1)$ & $5(15.2)$ & $11(57.9)$ & $5(23.8)$ & 31 \\
\hline \multicolumn{8}{|l|}{$\begin{array}{l}\text { Geographical region where } \\
\text { intervention was implemented* }\end{array}$} \\
\hline North America & $46(90.2)$ & $1(33.3)$ & $6(85.7)$ & $3(9.1)$ & - & $13(61.9)$ & 65 \\
\hline Europe & $4(7.8)$ & $2(66.7)$ & - & $28(84.8)$ & $16(84.2)$ & $7(33.3)$ & 53 \\
\hline Asia & - & - & $1(14.3)$ & $3(9.1)$ & $2(10.5)$ & - & 6 \\
\hline Australasia & $1(2.0)$ & - & - & - & - & $1(4.8)$ & 2 \\
\hline Africa & - & - & - & - & $1(5.3)$ & - & 1 \\
\hline South America & $1(2.0)$ & - & - & - & - & - & 1 \\
\hline \multicolumn{8}{|l|}{ Population studied $†$} \\
\hline Beef cattle & $4(7.8)$ & - & - & $3(9.1)$ & $1(5.3)$ & $6(28.6)$ & 14 \\
\hline Dairy cattle & $10(19.6)$ & - & $1(14.3)$ & $9(27.3)$ & - & - & 19 \\
\hline Poultry & $24(47.1)$ & $2(66.7)$ & $5(71.4)$ & $13(39.4)$ & $16(84.2)$ & $13(61.9)$ & 69 \\
\hline Swine & $17(33.3)$ & $2(66.7)$ & $1(14.3)$ & $9(27.3)$ & $10(52.6)$ & $5(23.8)$ & 42 \\
\hline Goats & $2(3.9)$ & - & - & 1 & - & - & 3 \\
\hline \multicolumn{8}{|l|}{ Sample studied $\dagger$} \\
\hline Faeces/cloaca/caeca & $33(64.7)$ & $2(66.7)$ & $6(85.7)$ & $12(36.4)$ & $18(94.7)$ & $11(52.4)$ & 77 \\
\hline Meat or carcass & $16(31.4)$ & $1(33.3)$ & $2(28.6)$ & $10(30.3)$ & $4(21.1)$ & $11(52.4)$ & 42 \\
\hline Milk & $7(13.7)$ & - & - & $10(30.3)$ & - & - & 16 \\
\hline Eggs & $2(3.9)$ & - & - & $3(9.1)$ & - & - & 5 \\
\hline Nasal swabs & $2(3.9)$ & - & - & $1(3.0)$ & - & $3(14.3)$ & 6 \\
\hline \multicolumn{8}{|l|}{ Bacteria studied $\dagger$} \\
\hline Campylobacter spp. & $12(23.5)$ & $2(66.7)$ & $1(14.3)$ & $4(12.1)$ & $2(10.5)$ & $3(14.3)$ & 23 \\
\hline Enterococcus spp. & $7(13.7)$ & - & - & $4(12.1)$ & $14(73.7)$ & $5(23.8)$ & 29 \\
\hline Staphylococcus spp. & $8(15.7)$ & & - & $14(42.4)$ & - & $8(38.1)$ & 29 \\
\hline Enterobacteriaceae & $25(49.0)$ & 1 (33.3) & $7(100.0)$ & $20(60.6)$ & $3(15.8)$ & $10(47.6)$ & 63 \\
\hline Other & $4(7.8)$ & - & - & $6(18.2)$ & - & $2(9.5)$ & 11 \\
\hline
\end{tabular}

*One study included intervention group samples from Denmark and the USA and was therefore counted twice.

†Categories are not mutually exclusive and studies can be included in more than one category.

\section{Pooled proportions of antibiotic resistance in comparator groups}

The pooled proportion of bacterial isolates with antibiotic resistance in comparator groups was lowest for studies that single antibiotic-class restrictions (pooled proportion $0.163,95 \%$ CI 0.075 to 0.252 , see table 4 ), and highest for studies examining interventions that restricted growth promoter use only (pooled proportion $0.492,95 \%$ CI 0.261 to 0.723 ). The pooled proportions for complete restriction, all non-therapeutic use restriction and other/undetermined restriction were similar, between 0.32 and 0.34 .

\section{DISCUSSION}

Though our broader systematic review and meta-analysis was important in bringing to light the effectiveness of antibiotic use restrictions on decreasing antibiotic resistance in food-producing animals, what has remained unknown until now is how to best implement this broad 
Table 4 Meta-analysis stratified by intervention category

\begin{tabular}{llll}
\hline Intervention category* & $\begin{array}{l}\text { Number of } \\
\text { studies }\end{array}$ & $\begin{array}{l}\text { Baseline prevalence of AMR } \\
\mathbf{( 9 5 \% ~ C l ) \dagger}\end{array}$ & $\begin{array}{l}\text { Pooled absolute risk } \\
\text { difference (95\% Cl) }\end{array}$ \\
\hline Complete restriction & 51 & $0.320(0.165$ to 0.468$)$ & $-0.15(-0.18$ to -0.12$)$ \\
Single antibiotic-class restriction & 3 & $0.163(0.075$ to 0.252$)$ & $-0.02(-0.10$ to 0.05$)$ \\
Single antibiotic restriction & 7 & $0.405(0.027$ to 0.784$)$ & $-0.11(-0.21$ to 0.01$)$ \\
All non-therapeutic use restriction & 33 & $0.322(0.076$ to 0.568$)$ & $-0.10(-0.13$ to -0.08$)$ \\
Growth promoter restriction & 19 & $0.492(0.261$ to 0.723$)$ & $-0.30(-0.42$ to -0.17$)$ \\
Other/undetermined & 21 & $0.338(0.082$ to 0.593$)$ & $-0.09(-0.13$ to -0.06$)$ \\
\hline
\end{tabular}

*Meta-regression joint $\mathrm{p}$-value $=0.046$.

†Pooled proportion of resistance in the comparator group.

AMR, antimicrobial resistance.

principle into practice and policy. This subanalysis plays a critical role in providing answers that can guide antibiotic use strategies in food-producing animals.

We demonstrate that highly targeted interventions limiting the use of single antibiotics or a single class of antibiotics are unlikely to be effective in reducing overall AMR. One reason for this finding may be that the use of the restricted antibiotic(s) is simply replaced by other antibiotics, such that there is no overall reduction in antibiotic use. This phenomenon was seen in Denmark. After the ban on the antibiotic growth promoter avoparcin, there was increased use of other growth promoters, including tylosin and virginiamycin, in its place. ${ }^{131}$ Furthermore, there may be continued resistance to certain antibiotic classes even after selected classes have been banned or restricted because of co-selection. Because genes that encode resistance to different antibiotics may be linked (ie, carried on the same mobile genetic element), the continued use of just one of these antibiotics is sufficient to select for all of the linked resistance mechanisms to the different antibiotics. ${ }^{163}$ This phenomenon was described in pigs where macrolide and glycopeptide resistance genes were linked. In this case, the ban of avoparcin did not result in reduced glycopeptide resistance, due to continued macrolide use. ${ }^{164165}$

Conversely, a complete ban on the use of all antibiotics in food-producing animals does not appear to be necessary. Though antibiotic-free practices were associated with a $15 \%$ reduction in antibiotic resistance, less prohibitive practices are associated with similar reductions. Given that complete restrictions do not appear superior in this regard, and with the added economic, production and ethical challenges of such practices, complete bans are not recommended. Beyond this, it is more difficult to ascertain whether certain less-restrictive types of interventions are superior to others.

At first glance, interventions that restrict antibiotic growth promoters appear to be most effective at reducing AMR in food-producing animals (RD $-0.30,95 \%$ CI -0.42 to 0.17$)$. However, growth promoter bans are often the first types of restrictions implemented; other interventions such as those limiting other non-therapeutic uses of antibiotics or all uses of antibiotics tend to be later interventions that are implemented after growth promoter bans or after other efforts to reduce antibiotic use are already in place. The large effect of antibiotic growth promoter bans relative to those of other interventions may therefore be due to the different comparator groups across the different interventions. Lending support to this hypothesis is that growth promoter ban studies tended to be published earlier (median year of publication 2001, IQR 2000-2004) compared with studies examining all other types of interventions (median 2010, IQR 2006-2015). Further support is provided through stratified meta-analysis of baseline proportions of isolates demonstrating antibiotic resistance. As predicted, the pooled baseline proportion of antibiotic resistance for growth promoter ban studies was higher compared with non-therapeutic antibiotic restriction and complete restriction studies (49\% vs 32\%). The smaller effect size for non-therapeutic restriction studies may therefore be explained, at least in part, by the lower baseline risk of antibiotic resistance (resulting in smaller RDs even if relative effects of the intervention are as large as the ones seen with growth promoter ban studies) and/or the smaller incremental benefit to antibiotic restriction once strategies to ban growth promotion claims on medically important antibiotics are already in place. We therefore cannot conclude that restrictions that target antibiotic growth promoters alone are more effective in reducing AMR compared with restrictions that target non-therapeutic indications more broadly. On the other hand, we have demonstrated that antibiotic growth promoter bans are effective in reducing AMR and therefore recommend that these be implemented on a global scale.

There are limitations to this systematic review. First, the comparison among intervention types through stratified analysis is inferior to comparison through head-to-head randomised controlled trials. However, such head-tohead randomised comparisons of different antibiotic restriction strategies do not exist in the primary literature. Furthermore, our stratified analysis findings are powerful especially as the differences in outcome effect across intervention types are consistent with prior experience and are biologically plausible (particularly the finding that very narrow restrictions are ineffective in 
reducing AMR while broader restrictions are). Second, there is known clinical heterogeneity across studies, with different countries, livestock production sectors, animal groups and resistance to different bacterial species included. Despite this, our original systematic review and meta-analysis demonstrated consistency in findings across many different layers of stratification, suggesting the presence of an overall effect. Third, we were limited in our classification of interventions by the lack of detailed description of interventions within primary studies. Similarly, because the majority of studies did not provide any description of the implementation process, we were not able to assess how the quality of implementation may affect the effectiveness of interventions in reducing AMR. Our analysis suggests that well-implemented interventions that have national certification standards (eg, for organic production) may be more effective than interventions that have similar claims but no such standard (eg, 'antibiotic-free' products). The former was categorised as 'complete restriction' (if undertaken in the USA), which was associated with a $15 \%$ reduction in antibiotic resistance, while the latter was classified in the 'other/undetermined' category, which was associated with a $9 \%$ reduction. A more in-depth analysis, though, could not be completed without more information and description about implementation of each intervention in the primary studies. Lastly, the vast majority of studies originated from either North America or Europe. Generalisability of these findings to other jurisdictions may be limited, particularly in low-income countries where there may be limited access to veterinarians, less investment in biosecurity ${ }^{166}$ and different antimicrobial use patterns.

Though we previously found that interventions that restrict antibiotic use in food-producing animals in general are effective in reducing $\mathrm{AMR},{ }^{14}$ the practical applications were limited due to the broad nature of the research question and analyses. It has been unclear until now which specific interventions should or should not be recommended to achieve the goal of reducing AMR. This substudy provides insight to these policy-relevant questions. We show that broad interventions that restrict the use of a full spectrum of antibiotic classes are needed. We also show, however, that complete bans on all antibiotic use are not necessary, as judicious use of antibiotics (such as for the treatment of clinical disease in affected animals) does not appear to hinder efforts to reduce AMR. These findings have directly informed WHO Guidelines on use of medically important antimicrobials in food-producing animals, ${ }^{20}$ and are directly relevant to public health policy globally.

\footnotetext{
Author affiliations

${ }^{1}$ Department of Medicine, Cumming School of Medicine, University of Calgary, Calgary, Alberta, Canada

${ }^{2}$ Department of Ecosystem and Public Health, Faculty of Veterinary Medicine, University of Calgary, Calgary, Alberta, Canada

${ }^{3}$ Department of Production Animal Health, Faculty of Veterinary Medicine, University of Calgary, Calgary, Alberta, Canada
}

${ }^{4}$ Department of Community Health Sciences, Cumming School of Medicine, University of Calgary, Calgary, Alberta, Canada

${ }^{5}$ W21C Research and Innovation Centre, Cumming School of Medicine, University of Calgary, Calgary, Alberta, Canada

${ }^{6}$ Libraries and Cultural Resources, University of Calgary, Calgary, Alberta, Canada ${ }^{7}$ Department of Pediatrics, Cumming School of Medicine, University of Calgary, Calgary, Alberta, Canada

Acknowledgements This study was commissioned and paid for by the WHO. Copyright in the original work on which this article is based belongs to the WHO. The authors have been given permission to publish this article.

Contributors Each of the 12 authors meets the authorship requirements as established by the International Committee of Medical Journal Editors in the Uniform Requirements for Manuscripts Submitted to Biomedical Journals. All authors were involved in the design and development of the study. HG created the search strategy and conducted the literature search in electronic databases. DN conducted the grey literature search. KT and NC screened all studies for inclusion into the systematic review and performed all study quality assessments. SC, PR and HB provided input on studies where consensus could not be reached. KT, NC, DN, AP and NS performed data extraction. All authors contributed to data interpretation and data analysis. KT drafted the manuscript and all authors revised it critically for content. All authors have read and approved the manuscript. KT accepts full responsibility for the work and conduct of the study, had access to the data and controlled the decision to publish. The corresponding author (KT) attests that all listed authors meet authorship criteria and that no others meeting the criteria have been omitted.

Funding This study was funded by World Health Organization.

Disclaimer The authors alone are responsible for the views expressed in this publication and do not necessarily represent the views, decisions, or policies of the World Health Organization.

Competing interests $\mathrm{JK}$ has an unrestricted grant as a principal investigator from Pfizer Canada to conduct an epidemiological study of invasive pneumococcal disease in humans, including impact of pneumococcal vaccines, and has a contract with GSK Canada as a local co-investigator a clinical trial of a maternal pertussis vaccine; no other relationships or activities that could appear to have influenced the submitted work. All other authors report no other relationships or activities that could appear to have influenced the submitted work.

Patient consent for publication Not required.

Provenance and peer review Not commissioned; externally peer reviewed. Data availability statement Data are available upon reasonable request.

Open access This is an open access article distributed in accordance with the Creative Commons Attribution Non Commercial (CC BY-NC 4.0) license, which permits others to distribute, remix, adapt, build upon this work non-commercially, and license their derivative works on different terms, provided the original work is properly cited, appropriate credit is given, any changes made indicated, and the use is non-commercial. See: http://creativecommons.org/licenses/by-nc/4.0/.

\section{REFERENCES}

1. de Kraker MEA, Davey PG, Grundmann H, et al. Mortality and hospital stay associated with resistant Staphylococcus aureus and Escherichia coli bacteremia: estimating the burden of antibiotic resistance in Europe. PLoS Med 2011:8:e1001104.

2. de Kraker MEA, Wolkewitz M, Davey PG, et al. Burden of antimicrobial resistance in European hospitals: excess mortality and length of hospital stay associated with bloodstream infections due to Escherichia coli resistant to third-generation cephalosporins. J Antimicrob Chemother 2011;66:398-407.

3. Cosgrove SE. The relationship between antimicrobial resistance and patient outcomes: mortality, length of hospital stay, and health care costs. Clin Infect Dis 2006;42:S82-9.

4. Cosgrove SE, Carmeli Y. The impact of antimicrobial resistance on health and economic outcomes. Clin Infect Dis 2003;36:1433-7.

5. O'Neill J. The Review on Antimicrobial Resistance: Tackling drugresistant infections globally - Final report and Recommendations. UK, 2016

6. Laxminarayan R, Duse A, Wattal C, et al. Antibiotic resistance-the need for global solutions. Lancet Infect Dis 2013;13:1057-98.

7. World Health Organization. Global principles for the containment of antimicrobial resistance in animals intended for food: report of a 
who consultation with the participation of the food and agriculture organization of the United nations and the. Geneva, Switzerland: Office International des Epizooties, 2000.

8. World Health Organization. Joint FAO/OIE/WHO expert workshop on non-human antimicrobial usage and antimicrobial resistance: scientific asssessment. Geneva, Switzerland, 2003.

9. World Health Organization. Critically important antibacterial agents for human medicine for risk management strategies of non-human use: report of a who Working group consultation. Canberra, Australia, 2005

10. World Health Organization. Antimicrobial use in aquaculture and antimicrobial resistance. Report of a joint FAO/OIE/WHO expert consultation on antimicrobial use in aquaculture and antimicrobial resistance. Seoul, Republic of Korea, 2006.

11. Tuševljak N, Dutil L, Rajić A, et al. Antimicrobial use and resistance in aquaculture: findings of a globally administered survey of aquaculture-allied professionals. Zoonoses Public Health 2013;60:426-36.

12. Food and Agriculture Organization of the United Nations. Joint FAO/WHO/OIE expert meeting on critically important antimicrobials. Rome, 2008: 60 .

13. World Health Organization, Food and Agriculture Organization of the United Nations, World Organisation for Animal Health. A manual for developing national action plans. Geneva, 2016.

14. Tang KL, Caffrey NP, Nóbrega DB, et al. Restricting the use of antibiotics in food-producing animals and its associations with antibiotic resistance in food-producing animals and human beings: a systematic review and meta-analysis. Lancet Planet Health 2017;1:e316-27.

15. Landers TF, Cohen B, Wittum TE, et al. A review of antibiotic use in food animals: perspective, policy, and potential. Public Health Rep 2012;127:4-22.

16. Casewell M, Friis C, Marco E, et al. The European ban on growthpromoting antibiotics and emerging consequences for human and animal health. J Antimicrob Chemother 2003;52:159-61.

17. Cogliani $\mathrm{C}$, Goossens $\mathrm{H}$, Greko $\mathrm{C}$. Restricting antimicrobial use in food animals: lessons from Europe. Microbe 2011;6:274-9.

18. Karavolias J, Salois MJ, Baker KT, et al. Raised without antibiotics: impact on animal welfare and implications for food policy. Transl Anim Sci 2018;2:337-48.

19. Phillips I, Casewell M, Cox T, et al. Does the use of antibiotics in food animals pose a risk to human health? A critical review of published data. J Antimicrob Chemother 2004;53:28-52.

20. World Health Organization. Who guidelines on use of medically important antimicrobials in food-producing animals, Geneva, 2017. Available: http://apps.who.int/iris/bitstream/handle/10665/258970/ 9789241550130-eng.pdf;jsessionid=FC6969336920B3D0DA15 0C31EF36D25B? sequence $=1$ [Accessed 20 Dec 2018].

21. Moher D, Liberati A, Tetzlaff J, et al. Preferred reporting items for systematic reviews and meta-analyses: the PRISMA statement. Ann Intern Med 2009;151:264-9.

22. WHO Advisory Group on Integrated Surveillance of Antimicrobial Resistance (AGISAR). Critically important antimicrobials for human medicine, 2011. Available: http://apps.who.int/iris/bitstream/10665/ 77376/1/9789241504485_eng.pdf [Accessed 11 Dec 2018]

23. World Organisation for Animal Health (OIE).. OIE list of antimicrobial agents of veterinary importance, 2015. Available: http://www.oie. int/fileadmin/Home/eng/Our_scientific_expertise/docs/pdf/Eng_ OIE_List_antimicrobials_May2015.pdf [Accessed 30 Jun 2016].

24. Downs SH, Black N. The feasibility of creating a checklist for the assessment of the methodological quality both of randomised and non-randomised studies of health care interventions. J Epidemio Community Health 1998;52:377-84

25. U.S. Department of Agriculture. Feedlot 2011, part IV: health and health management on U.S. feedlots with a capacity of 1,000 or more head Fort Collins, Colorado, 2013. Available: https:// www.aphis.usda.gov/animal_health/nahms/feedlot/downloads/ feedlot2011/Feed11_dr_PartIV.pdf [Accessed 18 Sep 2018].

26. European Medicines Agency. Guideline for the demonstration of efficacy for veterinary medicinal products containing antimicrobial substances London, United Kingdom, 2016. Available: https:// www.ema.europa.eu/documents/scientific-guideline/final-guidelinedemonstration-efficacy-veterinary-medicinal-products-containingantimicrobial_en.pdf [Accessed 18 Sep 2018].

27. Codex Alimentarius. Code of practice to minimize and contain antimicrobial resistance, CAC/RCP 61-2005: food and agriculture organization of the United nations / World Health organization, 2005. Available: http://www.fao.org/fao-who-codexalimentarius/ sh-proxy/fr/?lnk=1\&url=https\%253A\%252F\%252Fworkspace. fao.org\%252Fsites\%252Fcodex\%252FStandards\%252FCAC $\%$ 2BRCP\%2B61-2005\%252FCXP_061e.pdf [Accessed 7 Feb 2018].
28. U.S. Department of Agriculture. Organic livestock requirements, 2013. Available: https://www.ams.usda.gov/sites/default/files/ media/Organic\%20Livestock\%20Requirements.pdf

29. European Union Commission. Commission regulation (EC) NO 889/2008: laying down detailed rules for the implementation of Council regulation (EC) NO 834/2007 on organic production and labelling of organic products with regard to organic production, labelling and control 2008.

30. European Union Commission. Agriculture and rural development: organic farming, 2017. Available: http://ec.europa.eu/agriculture/ organic/eu-policy/eu-rules-on-production/livestock_en [Accessed 27 Jan 2017].

31. DerSimonian R, Kacker R. Random-effects model for meta-analysis of clinical trials: an update. Contemp Clin Trials 2007;28:105-14.

32. Higgins JPT, Thompson SG. Quantifying heterogeneity in a metaanalysis. Stat Med 2002;21:1539-58.

33. Higgins JPT, Thompson SG, Deeks JJ, et al. Measuring inconsistency in meta-analyses. BMJ 2003;327:557-60.

34. Harbord RM, Higgins JPT. Meta-Regression in Stata. Stata J 2008:8:493-519.

35. Aarestrup FM. Occurrence of glycopeptide resistance among Enterococcus faecium isolates from conventional and ecological poultry farms. Microb Drug Resist 1995;1:255-7.

36. Abdalrahman L, Stanley A, Wells $\mathrm{H}$, et al. Isolation, virulence, and antimicrobial resistance of methicillin-resistant Staphylococcus aureus (MRSA) and methicillin sensitive Staphylococcus aureus (MSSA) strains from Oklahoma retail poultry meats. Int J Environ Res Public Health 2015;12:6148-61.

37. Antimicrobial resistance of enteric bacteria among ceftiofur treated and non-antimicrobial treated co-mingled pasture beef cows. 4Th ASM conference on antimicrobial resistance in zoonotic bacteria and foodborne pathogens. Washington, United States, 2015.

38. Alali WQ, Thakur S, Berghaus RD, et al. Prevalence and distribution of Salmonella in organic and conventional broiler poultry farms. Foodborne Pathog Dis 2010;7:1363-71.

39. Bailey MA, Taylor RM, Brar JS, et al. Prevalence and antimicrobial resistance of Campylobacter from antibiotic-free broilers during organic and conventional processing. Poult Sci 2019;98:1447-54.

40. Bombyk RAM, Bykowski AL, Draper CE, et al. Comparison of types and antimicrobial susceptibility of Staphylococcus from conventional and organic dairies in west-central Minnesota, USA. $J$ Appl Microbiol 2008;104:1726-31.

41. Bunner CA, Norby B, Bartlett PC, et al. Prevalence and pattern of antimicrobial susceptibility in Escherichia coli isolated from pigs reared under antimicrobial-free and conventional production methods. J Am Vet Med Assoc 2007;231:275-83.

42. Cho S, Fossler CP, Diez-Gonzalez F, et al. Antimicrobial Susceptibility of Shiga Toxin-Producing Escherichia coli Isolated from Organic Dairy Farms, Conventional Dairy Farms, and County Fairs in Minnesota. Foodborne Pathog Dis 2007;4:178-86.

43. Cicconi-Hogan KM, Belomestnykh N, Gamroth M, et al. Short communication: prevalence of methicillin resistance in coagulasenegative staphylococci and Staphylococcus aureus isolated from bulk milk on organic and conventional dairy farms in the United States. J Dairy Sci 2014;97:2959-64.

44. Cui S. Detection and characterization of Escherichia coli O157:H7 and Salmonella in food [Ph. D.]. University of Maryland, College Park 2004

45. Cui S, Ge B, Zheng J, et al. Prevalence and antimicrobial resistance of Campylobacter spp. and Salmonella serovars in organic chickens from Maryland retail stores. Appl Environ Microbiol 2005; $71: 4108-11$

46. Cuny C, Friedrich AW, Witte W. Absence of livestock-associated methicillin-resistant Staphylococcus aureus clonal complex CC398 as a nasal colonizer of pigs raised in an alternative system. Appl Environ Microbiol 2012;78:1296-7.

47. Gebreyes WA, Thakur S, Morrow WEM. Comparison of prevalence, antimicrobial resistance, and occurrence of multidrug-resistant Salmonella in antimicrobial-free and conventional pig production. $J$ Food Prot 2006:69:743-8.

48. Gellin G, Langlois BE, Dawson KA, et al. Antibiotic resistance of gram-negative enteric bacteria from pigs in three herds with different histories of antibiotic exposure. Appl Environ Microbiol 1989;55.

49. Halbert LW, Kaneene JB, Linz J, et al. Genetic mechanisms contributing to reduced tetracycline susceptibility of Campylobacter isolated from organic and conventional dairy farms in the midwestern and northeastern United States. J Food Prot 2006;69:482-8

50. Halbert LW, Kaneene JB, Ruegg PL, et al. Evaluation of antimicrobial susceptibility patterns in Campylobacter spp isolated 
from dairy cattle and farms managed organically and conventionally in the midwestern and northeastern United States. J Am Vet Med Assoc 2006;228:1074-81.

51. Han F, Lestari SI, Pu S, et al. Prevalence and Antimicrobial Resistance Among Campylobacter spp. in Louisiana Retail Chickens After the Enrofloxacin Ban. Foodborne Pathog Dis 2009;6:163-71.

52. Joseph S, Sapkota A, Cullen P, et al. Reduced resistance to antibiotics among Salmonella spp. recovered from U.S. organic poultry farms. antimicrobial resistance in zoonotic bacteria and foodborne pathogens in animals, humans and the environment. American Society for Microbiology 2008;17.

53. Joseph SW, Paramadhas R, Cullen P, et al. Reduced resistance to antibiotics among Enterococcus faecium of organic poultry farm origin. Abstracts of the Interscience conference on antimicrobial agents and chemotherapy 2007;47:95-6.

54. Kassem II, Kehinde O, Kumar A, et al. Antimicrobial-Resistant Campylobacter in Organically and Conventionally Raised Layer Chickens. Foodborne Pathog Dis 2017;14:29-34.

55. Keelara S, Scott HM, Morrow WM, et al. Longitudinal study of distributions of similar antimicrobial-resistant Salmonella serovars in pigs and their environment in two distinct swine production systems. Appl Environ Microbiol 2013;79:5167-78.

56. Kieke AL, Borchardt MA, Kieke BA, et al. Use of Streptogramin Growth Promoters in Poultry and Isolation of StreptograminResistant Enterococcus faecium from Humans. J Infect Dis 2006;194:1200-8.

57. Langlois BE, Cromwell GL, Stahly TS, et al. Antibiotic resistance of fecal coliforms after long-term withdrawal of therapeutic and subtherapeutic antibiotic use in a swine herd. Appl Environ Microbiol 1983;46:1433-4

58. Langlois $\mathrm{BE}$, Dawson $\mathrm{K}$, Cromwell G, et al. Antibiotic resistance in pigs following a 13 year ban. J Anim Sci 1986;62(Suppl. 3):18-32.

59. Lestari SIKA, Han F, Wang FEl, et al. Prevalence and antimicrobial resistance of Salmonella serovars in conventional and organic chickens from Louisiana retail stores. J Food Prot 2009;72:1165-72.

60. Lou R. Dietary mannan-oligosaccharide as an approach for altering prevalence of antibiotic resistance and distribution of tetracycline resistance determinants in fecal bacteria from swine [Ph.D]. University of Kentucky, 1995.

61. Luangtongkum T, Morishita TY, Ison AJ, et al. Effect of conventional and organic production practices on the prevalence and antimicrobial resistance of Campylobacter spp. in poultry. Appl Environ Microbiol 2006;72:3600-7.

62. Nulsen MF, Mor MB, Lawton DEB. Antibiotic resistance among indicator bacteria isolated from healthy pigs in New Zealand. $N Z$ Vet $J$ 2008;56:29-35.

63. Peng M, Salaheen S, Almario JA, et al. Prevalence and antibiotic resistance pattern of Salmonella serovars in integrated croplivestock farms and their products sold in local markets. Environ Microbiol 2016;18:1654-65.

64. Pettey EA. Comparison of antibiotic susceptibility characteristics of fecal lactobacilli and the distribution of tetracycline resistance genes on two swine farms with different histories of antibiotic use [Ph.D]. University of Kentucky, 2008.

65. Pol M, Ruegg PL. Relationship between antimicrobial drug usage and antimicrobial susceptibility of gram-positive mastitis pathogens. J Dairy Sci 2007;90:262-73.

66. Price LB, Johnson E, Vailes R, et al. Fluoroquinolone-Resistant Campylobacter Isolates from Conventional and Antibiotic-Free Chicken Products. Environ Health Perspect 2005;113:557-60.

67. Price LB, Lackey LG, Vailes R, et al. The Persistence of Fluoroquinolone-Resistant Campylobacter in Poultry Production. Environ Health Perspect 2007;115:1035-9.

68. Ray KA, Warnick LD, Mitchell RM, et al. Antimicrobial susceptibility of Salmonella from organic and conventional dairy farms. J Dairy Sci 2006;89:2038-50.

69. Rollo SN, Norby B, Bartlett PC, et al. Prevalence and patterns of antimicrobial resistance in Campylobacter spp isolated from pigs reared under antimicrobial-free and conventional production methods in eight states in the Midwestern United States. J Am Vet Med Assoc 2010;236:201-10.

70. Rossa LS, EvR S, Diez DC, et al. Antimicrobial resistance and occurrence of indicator and pathogenic bacteria in organic and conventional chicken meat: comparative study. Biotemas 2013;26:211-20.

71. Salaheen S, Peng M, Biswas D. Ecological dynamics of Campylobacter in integrated mixed crop-livestock farms and its prevalence and survival ability in post-harvest products. Zoonoses Public Health 2016;13.
72. Sanchez HM. Antibiotic resistance in bacteria isolated from commercial meat samples and air samples near agricultural sites [Ph.D. Los Angeles: University of California, 2015.

73. Sapkota AR, Hulet RM, Zhang G, et al. Lower prevalence of antibiotic-resistant enterococci on U.S. conventional poultry farms that transitioned to organic practices. Environ Health Perspect 2011:119:1622-8.

74. Sapkota AR, Kim A, Hulet RM, et al. Trends in the prevalence and antibiotic-resistance of Salmonella after conventional poultry farms transition to organic practices. Abstr Gen Meet Am Soc Microbiol 2010;110

75. Sapkota AR, Kinney EL, George A, et al. Lower prevalence of antibiotic-resistant Salmonella on large-scale U.S. conventional poultry farms that transitioned to organic practices. Sci Total Environ 2014:476-477:387-92.

76. Sato K, Bartlett PC, Saeed MA. Antimicrobial susceptibility of Escherichia coli isolates from dairy farms using organic versus conventional production methods. J Am Vet Med Assoc 2005;226:589-94

77. Sato K, Bennedsgaard TW, Bartlett PC, et al. Comparison of antimicrobial susceptibility of Staphylococcus aureus isolated from bulk tank milk in organic and conventional dairy herds in the midwestern United States and Denmark. J Food Prot 2004;67:1104-10

78. Siemon CE, Bahnson PB, Gebreyes WA. Comparative investigation of prevalence and antimicrobial resistance of Salmonella between pasture and conventionally reared poultry. Avian Dis 2007:51:112-7.

79. Smith TC, Gebreyes WA, Abley MJ, et al. Methicillin-Resistant Staphylococcus aureus in pigs and farm workers on conventional and antibiotic-free swine farms in the USA. PLoS One 2013;8:e63704

80. Thakur S, Gebreyes WA. Prevalence and antimicrobial resistance of Campylobacter in antimicrobial-free and conventional pig production systems. J Food Prot 2005;68:2402-10.

81. Tikofsky LL, Barlow JW, Santisteban C, et al. A Comparison of antimicrobial susceptibility patterns for Staphylococcus aureus in organic and conventional dairy herds. Microbial Drug Resistance 2003;9(supplement 1):39-45.

82. Vikram A, Rovira P, Agga GE, et al. Impact of "Raised without Antibiotics" beef cattle production practices on occurrences of antimicrobial resistance. Appl Environ Microbiol 2017;83.

83. Wanninger S, Donati M, Di Francesco A, et al. Selective pressure promotes tetracycline resistance of Chlamydia suis in fattening pigs. PLoS One 2016;11:e0166917.

84. Zhang J, Massow A, Stanley M, et al. Contamination rates and antimicrobial resistance in Enterococcus spp., Escherichia coli, and Salmonella isolated from "no antibiotics added"-labeled chicken products. Foodborne Pathog Dis 2011:8:1147-52.

85. Zwonitzer MR, Soupir ML, Jarboe LR, et al. Quantifying attachment and antibiotic resistance of from conventional and organic swine manure. J Environ Qual 2016;45:609-17.

86. Agers $\varnothing$ Y, Aarestrup FM. Voluntary ban on cephalosporin use in Danish pig production has effectively reduced extended-spectrum cephalosporinase-producing Escherichia coli in slaughter pigs. $J$ Antimicrob Chemother 2013;68:569-72.

87. Gallay A, Prouzet-Mauléon V, Kempf I, et al. Campylobacter antimicrobial drug resistance among humans, broiler chickens, and pigs, France. Emerg Infect Dis 2007;13:259-66.

88. Nannapaneni R, Hanning I, Wiggins KC, et al. Ciprofloxacinresistant Campylobacter persists in raw retail chicken after the fluoroquinolone ban. Food Addit Contam Part $A$ 2009;26:1348-53.

89. Agunos A, Arsenault RK, Avery BP, et al. Changes in antimicrobial resistance levels among Escherichia coli, Salmonella, and Campylobacter in Ontario broiler chickens between 2003 and 2015 Can J Vet Res 2018;82:163-77.

90. Bauer-Garland J, Frye JG, Gray JT, et al. Transmission of Salmonella enterica serotype typhimurium in poultry with and without antimicrobial selective pressure. J Appl Microbiol 2006; 101:1301-8

91. Dutil L, Irwin R, Finley R, et al. Ceftiofur Resistance in Salmonella enterica Serovar Heidelberg from Chicken Meat and Humans, Canada. Emerg Infect Dis 2010;16:48-54.

92. Hiki M, Kawanishi M, Abo H, et al. Decreased Resistance to Broad-Spectrum Cephalosporin in Escherichia coli from Healthy Broilers at Farms in Japan After Voluntary Withdrawal of Ceftiofur. Foodborne Pathog Dis 2015;12:639-43.

93. Patchanee P. Epidemiology of Salmonella enterica related to swine production system and food safety [Ph.D]. The Ohio State University, 2008. 
94. Tragesser LA, Wittum TE, Funk JA, et al. Association between ceftiofur use and isolation of Escherichia coli with reduced susceptibility to ceftriaxone from fecal samples of dairy cows. Am J Vet Res 2006:67:1696-700.

95. Verrette L, Fairbrother JM, Boulianne M. Effect of Cessation of Ceftiofur and Substitution with Lincomycin-Spectinomycin on Extended-Spectrum- $\beta$-Lactamase/AmpC Genes and Multidrug Resistance in Escherichia coli from a Canadian Broiler Production Pyramid. Appl Environ Microbiol 2019;85. doi:10.1128/AEM.0003719. [Epub ahead of print: 01 Jul 2019].

96. Álvarez-Fernández E, Cancelo A, Díaz-Vega C, et al. Antimicrobial resistance in $\mathrm{E}$. coli isolates from conventionally and organically reared poultry: A comparison of agar disc diffusion and Sensi Test Gram-negative methods. Food Control 2013;30:227-34.

97. Alvarez-Fernandez E, Dominguez-Rodriguez J, Capita R, et al. Influence of housing systems on microbial load and antimicrobial resistance patterns of Escherichia coli isolates from eggs produced for human consumption. J Food Prot 2012;75:847-53.

98. Bennedsgaard TW, Thamsborg SM, Aarestrup FM, et al. Resistance to penicillin of Staphylococcus aureus isolates from cows with high somatic cell counts in organic and conventional dairy herds in Denmark. Acta Vet Scand 2006;48:24.

99. Boutet P, Detilleux J, Motkin M, et al. A comparison of somatic cell count and antimicrobial susceptibility of subclinical mastitis pathogens in organic and conventional dairy herds. Ann Med Vet 2005;149:173-82.

100. Cohen Stuart J, van den Munckhof T, Voets G, et al. Comparison of ESBL contamination in organic and conventional retail chicken meat. Int J Food Microbiol 2012;154:212-4.

101. El-Shibiny A, Connerton PL, Connerton IF. Enumeration and diversity of campylobacters and bacteriophages isolated during the rearing cycles of free-range and organic chickens. Appl Environ Microbiol 2005;71:1259-66.

102. Fraqueza MJ, Martins A, Borges AC, et al. Antimicrobial resistance among Campylobacter spp. strains isolated from different poultry production systems at slaughterhouse level. Poult Sci 2014;93:1578-86.

103. Garmo RT, Waage S, Sviland S, et al. Reproductive performance, udder health, and antibiotic resistance in mastitis bacteria isolated from Norwegian red cows in conventional and organic farming. Acta Vet Scand 2010;52:11.

104. Guarddon M, Miranda JM, Rodríguez JA, et al. Quantitative detection of tetracycline-resistant microorganisms in conventional and organic beef, pork and chicken meat. CyTA - Journal of Food 2014;12:383-8.

105. Huijbers PMC, van Hoek AHAM, Graat EAM, et al. MethicillinResistant Staphylococcus aureus and extended-spectrum and AmpC $\beta$-lactamase-producing Escherichia coli in broilers and in people living and/or working on organic broiler farms. Vet Microbiol 2015;176:120-5.

106. Kempf I, Kerouanton A, Bougeard S, et al. Campylobacter coli in organic and conventional pig production in France and Sweden: prevalence and antimicrobial resistance. Front Microbiol 2017;8:955

107. Kerouanton A, Rose V, Chidaine B, et al. Comparison of organic and conventional pig productions on prevalence, antibiotic resistance and genetic diversity of Escherichia coli Journées de la Recherche porcine en France 2014;46:179-80.

108. Kim Y-J, Park J-H, Seo K-H. Comparison of the loads and antibiotic-resistance profiles of Enterococcus species from conventional and organic chicken carcasses in South Korea. Poult Sci 2018:97:271-8.

109. Larsen JL, Nielsen NC. Influence of restrictive use of antibiotics on the development of drug resistance in intestinal Escherichia coli from pigs. Nord Vet Med 1975;27:353-64.

110. Malissiova E, Papadopoulos T, Kyriazi A, et al. Differences in sheep and goats milk microbiological profile between conventional and organic farming systems in Greece. Journal of Dairy Research 2017;84:206-13.

111. Meemken D, Blaha T. Research on the occurrence of methicillinresistant Staphylococcus aureus (MRSA) in domestic pigs and wild boars in Germany. Dtsch Tierarztl Wochenschr 2009;116:297-301.

112. Miranda JM, Guarddon M, Mondragon A, et al. Antimicrobial resistance in Enterococcus spp. strains isolated from organic chicken, conventional chicken, and turkey meat: a comparative survey. J Food Prot 2007;70:1021-4.

113. Miranda JM, Guarddon M, Vázquez BI, et al. Antimicrobial resistance in Enterobacteriaceae strains isolated from organic chicken, conventional chicken and conventional turkey meat: a comparative survey. Food Control 2008;19:412-6.
114. Miranda JM, Mondragón A, Vázquez Bl, et al. Influence of farming methods on microbiological contamination and prevalence of resistance to antimicrobial drugs in isolates from beef. Meat Sci 2009;82:284-8.

115. Miranda JM, Mondragón A, Vázquez Bl, et al. Microbiological quality and antimicrobial resistance of Escherichia coli and Staphylococcus aureus isolated from conventional and organic "Arzúa-Ulloa" cheese. CyTA - Journal of Food 2009;7:103-10.

116. Miranda JM, Vázquez BI, Fente CA, et al. Antimicrobial resistance in Escherichia coli strains isolated from organic and conventional pork meat: a comparative survey. Eur Food Res Technol 2008;226:371-5.

117. Miranda JM, Vazquez BI, Fente CA, et al. Comparison of antimicrobial resistance in Escherichia coli, Staphylococcus aureus, and Listeria monocytogenes strains isolated from organic and conventional poultry meat. J Food Prot 2008;71:2537-42.

118. Morley PS, Dargatz DA, Hyatt DR, et al. Effects of restricted antimicrobial exposure on antimicrobial resistance in fecal Escherichia coli from feedlot cattle. Foodborne Pathog Dis 2011;8:87-98.

119. O'Neill C. Antibiotic-resistant staphylococci in the agricultural environment: reservoirs of resistance and infection [Ph.D. University of Warwick, 2010.

120. Österberg J, Wingstrand A, Nygaard Jensen A, et al. Antibiotic resistance in Escherichia coli from pigs in organic and conventional farming in four European countries. PLoS One 2016;11:e0157049.

121. Roesch M, Perreten V, Doherr MG, et al. Comparison of antibiotic resistance of udder pathogens in dairy cows kept on organic and on conventional farms. J Dairy Sci 2006;89:989-97.

122. Sato K, Bartlett PC, Kaneene JB, et al. Comparison of prevalence and antimicrobial susceptibilities of Campylobacter spp. isolates from organic and conventional dairy herds in Wisconsin. Appl Environ Microbiol 2004;70:1442-7.

123. Schwaiger K, Schmied E-MV, Bauer J. Comparative analysis of antibiotic resistance characteristics of gram-negative bacteria isolated from laying hens and eggs in conventional and organic keeping systems in Bavaria, Germany. Zoonoses Public Health 2008:55:331-41.

124. Schwaiger K, Schmied E-MV, Bauer J. Comparative analysis on antibiotic resistance characteristics of Listeria spp. and Enterococcus spp. isolated from laying hens and eggs in conventional and organic keeping systems in Bavaria, Germany. Zoonoses Public Health 2010;57:171-80.

125. Suriyasathaporn W. Milk quality and antimicrobial resistance against mastitis pathogens after changing from a conventional to an experimentally organic dairy farm. Asian Australas. J. Anim. Sci 2010;23:659-64.

126. Tamang MD, Gurung M, Nam H-M, et al. Prevalence and characterization of Salmonella in pigs from conventional and organic farms and first report of S. serovar 1,4,[5],12:i:- from Korea. Vet Microbiol 2015;178:119-24.

127. Tenhagen B-A, Alt K, Pfefferkorn B, et al. Short communication: methicillin-resistant Staphylococcus aureus in conventional and organic dairy herds in Germany. J Dairy Sci 2018;101:3380-6.

128. Aarestrup FM, Bager F, Andersen JS. Association between the use of avilamycin for growth promotion and the occurrence of resistance among Enterococcus faecium from broilers: epidemiological study and changes over time. Microb Drug Resist 2000;6:71-5.

129. Aarestrup FM, Hasman H, Jensen LB, et al. Antimicrobial resistance among enterococci from pigs in three European countries. Appl Environ Microbiol 2002;68:4127-9.

130. Aarestrup FM, Kruse H, Tast E, et al. Associations Between the Use of Antimicrobial Agents for Growth Promotion and the Occurrence of Resistance among Enterococcus faecium from Broilers and Pigs in Denmark, Finland, and Norway. Microbial Drug Resistance 2000;6:63-70.

131. Aarestrup FM, Seyfarth AM, Emborg H-D, et al. Effect of abolishment of the use of antimicrobial agents for growth promotion on occurrence of antimicrobial resistance in fecal enterococci from food animals in Denmark. Antimicrob Agents Chemother 2001;45:2054-9.

132. Avrain L, Humbert F, L'Hospitalier R, et al. Antimicrobial resistance in Campylobacter from broilers: association with production type and antimicrobial use. Vet Microbiol 2003;96:267-76.

133. Boerlin P, Wissing A, Aarestrup FM, et al. Antimicrobial growth promoter ban and resistance to macrolides and vancomycin in enterococci from pigs. J Clin Microbiol 2001;39:4193-5.

134. Borgen K, Simonsen GS, Sundsfjord A, et al. Continuing high prevalence of VanA-type vancomycin-resistant enterococci on 
Norwegian poultry farms three years after avoparcin was banned. $J$ Appl Microbiol 2000;89:478-85.

135. Borgen K, Sørum M, Wasteson Y, et al. VanA-type vancomycinresistant enterococci (VRE) remain prevalent in poultry carcasses 3 years after avoparcin was banned. Int $J$ Food Microbiol 2001;64:89-94.

136. Del Grosso M, Caprioli A, Chinzari P, et al. Detection and characterization of vancomycin-resistant enterococci in farm animals and raw meat products in Italy. Microbial Drug Resistance 2000;6:313-8.

137. Desmonts $\mathrm{M}-\mathrm{H}$, Dufour-Gesbert F, Avrain L, et al. Antimicrobial resistance in Campylobacter strains isolated from French broilers before and after antimicrobial growth promoter bans. J Antimicrob Chemother 2004;54:1025-30.

138. Heuer OE, Pedersen K, Andersen JS, et al Vancomycin-Resistant enterococci (VRE) in broiler flocks 5 years after the avoparcin ban. Microbial Drug Resistance 2002;8:133-8.

139. Kruse H, Johansen BK, Rørvik LM, et al. The use of avoparcin as a growth promoter and the occurrence of vancomycin-resistant Enterococcus species in Norwegian poultry and swine production. Microb Drug Resist 1999;5:135-9.

140. Kuhn I, Iversen A, Finn M, et al. Occurrence and relatedness of vancomycin-resistant enterococci in animals, humans, and the environment in different European regions. Appl Environ Microbiol 2005;71:5383-90.

141. Lauderdale T-L, Shiau Y-R, Wang H-Y, et al. Effect of banning vancomycin analogue avoparcin on vancomycin-resistant enterococci in chicken farms in Taiwan. Environ Microbiol 2007;9:819-23.

142. Li W, Hou M, Liu C, et al. Dramatic decrease in colistin resistance in Escherichia coli from a typical pig farm following restriction of colistin use in China. Int J Antimicrob Agents 2019;53:707-8.

143. Nwankwo C, Ayogu T, Iroha I, et al. Cloacal feacal carriage and occurrence of antibiotic resistant Escherichia coli in chicken grown with and without antibiotic supplemented feed. J. Vet. Med. Anim. Health 2014;6:91-4.

144. Smith HW, Lovell MA. Escherichia coli resistant to tetracyclines and to other antibiotics in the faeces of U.K. chickens and pigs in 1980. J Hyg 1981;87:477-83.

145. Sørum M, Holstad G, Lillehaug A, et al. Prevalence of vancomycin resistant enterococci on poultry farms established after the ban of avoparcin. Avian Dis 2004:48:823-8.

146. van den Bogaard $A E$, Bruinsma N, Stobberingh $E E$. The effect of banning avoparcin on VRE carriage in the Netherlands. $J$ Antimicrob Chemother 2000;46:146-8.

147. Agunos A, Gow SP, Léger DF, et al. Antimicrobial use and antimicrobial resistance Indicators - Integration of Farm-Level surveillance data from broiler chickens and turkeys in British Columbia, Canada. Frontiers in Veterinary Science 2019;6.

148. Dorado-García A, Graveland H, Bos MEH, et al. Effects of reducing antimicrobial use and applying a cleaning and disinfection program in veal calf farming: experiences from an intervention study to control livestock-associated MRSA. PLoS One 2015;10:e0135826.

149. ESCMID/ASM Conference. Prevalence of methicillin-resistant Staphylococcus aureus (MRSA) in organic and confinement swine operations in the midwestern United States. London, UK, 2009.

150. Haskell KJ, Schriever SR, Fonoimoana KD, et al. Antibiotic resistance is lower in Staphylococcus aureus isolated from antibiotic-free RAW meat as compared to conventional RAW meat. PLoS One 2018;13:e0206712.
151. Hässig M, Eugster S, Lewis FI. Herd level antimicrobial resistance in beef calves in Switzerland 1986 through 2011. OJVM 2014;04:247-54.

152. Kilonzo-Nthenge A, Brown A, Nahashon SN, et al. Occurrence and antimicrobial resistance of enterococci isolated from organic and conventional retail chicken. J Food Prot 2015;78:760-6.

153. LeJEUNE JT, Christie NP. Microbiological Quality of Ground Beef from Conventionally-Reared Cattle and "Raised without Antibiotics" Label Claims. J Food Prot 2004;67:1433-7.

154. Lenart-Boron A, Augustyniak K, Boron P. Screening of antimicrobial resistance and molecular detection of fluoroquinolone resistance mechanisms in chicken faeces-derived Escherichia coli. Veterinarni Medicina 2016;61:80-9.

155. O'Brien AM, Hanson BM, Farina SA, et al. Mrsa in conventional and alternative retail pork products. PLoS One 2012;7:e30092.

156. Obeng AS, Rickard $\mathrm{H}$, Ndi O, et al. Antibiotic resistance, phylogenetic grouping and virulence potential of Escherichia coli isolated from the faeces of intensively farmed and free range poultry. Vet Microbiol 2012;154:305-15.

157. Tadesse DA. Molecular epidemiology of Campylobacter and Yersinia enterocolitica isolates from pigs reared in conventional and antibiotic free farms from different geographic regions [Ph.D]. The Ohio State University, 2009.

158. Teramoto H, Salaheen S, Biswas D. Contamination of postharvest poultry products with multidrug resistant Staphylococcus aureus in Maryland-Washington DC Metro area. Food Control 2016;65:132-5.

159. Thapaliya D, Forshey BM, Kadariya J, et al. Prevalence and molecular characterization of Staphylococcus aureus in commercially available meat over a one-year period in lowa, USA. Food Microbiol 2017;65:122-9.

160. van den Bogaard AEet al. Antibiotic resistance of faecal Escherichia coli in poultry, poultry farmers and poultry slaughterers. $J$ Antimicrob Chemother 2001;47:763-71.

161. Vikram A, Miller E, Arthur TM, et al. Similar Levels of Antimicrobial Resistance in U.S. Food Service Ground Beef Products with and without a "Raised without Antibiotics" Claim. J Food Prot 2018;81:2007-18.

162. Zhang Y. Antimicrobial resistance of Listeria monocytogenes and Enterococcus faecium from food and animal sources [Ph.D]. University of Maryland, College Park, 2005.

163. Wales A, Davies R. Co-selection of resistance to antibiotics, biocides and heavy metals, and its relevance to foodborne pathogens. Antibiotics 2015;4:567-604.

164. Aarestrup FM. Characterization of glycopeptide-resistant Enterococcus faecium (GRE) from broilers and pigs in Denmark: genetic evidence that persistence of GRE in pig herds is associated with coselection by resistance to macrolides. J Clin Microbiol 2000;38:2774-7.

165. Bager F, Aarestrup FM, Madsen M, et al. Glycopeptide resistance in Enterococcus faecium from broilers and pigs following discontinued use of avoparcin. Microb Drug Resist 1999;5:53-6.

166. Coker RJ, Hunter BM, Rudge JW, et al. Emerging infectious diseases in Southeast Asia: regional challenges to control. The Lancet 2011;377:599-609.

167. Paulson JA, Zaoutis TE. Nontherapeutic use of antimicrobial agents in animal agriculture: implications for pediatrics. Pediatrics 2015;136:e1670-7. 